\title{
Sciendo
}

Scientific Bulletin

Vol. XXIV, No 2 (48), 2019

\section{RETIREMENT, PREDICTIVE FACTORS OF RETIREMENT AND RETIREMENT ADJUSTMENT}

\author{
Gabriela-Maria MAN \\ gabriela.man@ulbsibiu.ro \\ Mihaela MAN \\ mihaela.man@ulbsibiu.ro \\ “LUCIAN BLAGA” UNIVERSITY, SIBIU, ROMANIA
}

\begin{abstract}
Today, retirement is a process that many people have access to. This is due to the fact that global life expectancy has increased, and in many countries retirement, as a form of remuneration after years of work, is guaranteed by social security funds. For many members of society, the accessibility of retirement creates the need to know more about it. In this respect, the present article addresses the issue of defining retirement and lists the main predictors of retirement, or those factors related to the continuation of professional activity. At the same time, this article lists several factors, identified in the literature, as predictive factors of adjustment after retirement.
\end{abstract}

\section{KEYWORDS:}

Retirement, aging employees, retirement adjustment, factors of retirement

\section{Introduction}

In general terms, retirement is regarded as a period when a person may leave paid work and is entitled to receive a pension as a result of years of service (Bowlby, 2007; Denton \& Spencer, 2009; Erber, 2013). However, this type of definition is insufficiently clear to capture the complexity of this aspect (Bowlby, 2007; Denton \& Spencer, 2009). For many researchers, retirement may reflect a process with three phases: the formation of the image of retirement; identifying the time of retirement; and transition into retirement (Beehr \& Bowling, 2013). By conceptualizing retirement as a process and a period, more variables may be considered: personal motivations, stages of development, social context, personal health and so on (Beehr \& Bowling, 2013).

\section{Retirement over time}

Today, "retirement" is a well-known concept, yet before the industrial revolution it was almost non-existent. What began as something intended only for a few groups of employees in the nineteenth and early twentieth centuries has, since the midtwentieth century up to today, grown to be the norm in many countries across the world (Zickar, 2013). The fact that before the industrial revolution there was no 
retirement can be explained by certain demographic aspects related to that period. For instance, reaching retirement age was a rarity, given that longevity was not something that many young adults could look forward to (Wilmoth, 2000). But in the twentieth and twenty-first centuries many people are reaching retirement age (Crampton, 2009; Dobriansky, Suzman \& Hobes, 2007; United Nations, 2009). In this sense, the context for the implementation of retirement was created by demographic changes.

The fact that retirement is currently an option for many people is visible by comparing labour force participation rates from the middle of the nineteenth century and those from the twentieth and twentyfirst centuries. In 1850 more than $90 \%$ of adults (men) aged 55-60 were professionally active and nearly $80 \%$ of those aged $65+$ years old were not retired. However, in 1990 fewer than $70 \%$ of those aged 55-60 years old were still professionally active; while for those over 65 years old, somewhere below $20 \%$ were still professionally active (Costa, 1998). In 2010 in Portugal, the employment rate between the ages of 55-64 years was $55 \%$; in the United Kingdom the employment rate between 55-64 years of age was $63 \%$; while $60 \%$ of Dutch people aged 55-64 years were active (Brunello \& Langella, 2012). The decrease of labour force participation rates since the mid-nineteenth century from $80-90 \%$ may be related to the financial comfort offered by pensions and better health conditions. However, the decline in labour force participation rates has also been influenced by the portrayal of retirement as a period of life related with leisure (Wheaton \& Crimmins, 2013).

\section{Retirement predictors and related factors}

Two types of factors affect decisions to retire: predictive factors, related to individual factors, and a series of organizational related factors (Jex \& Grosch, 2013). Among the individual factors that can be mentioned are one's own personal financial situation. Those employees who have many benefits for retirement (large private pensions, incentives from the organizations where they work, large personal savings, large pensions from social security systems, and so on), are more likely to retire earlier (Gruber \& Wise, 1998; Mein et al., 2000). Health can be another factor of concern that may precipitate a retirement decision (Topa, Moriano, Depolo, Alcover \& Morales, 2009). Certain health-related problems may increase with aging (Administration on Aging for Community, 2015), forcing older employees to consider this aspect. Age is also a predictor of professional retirement; as employees become older the desire to retire grows stronger (Davies \& Cartwright, 2011).

When it comes to organizational related factors, job satisfaction can greatly influence retirement. Those employees who are satisfied with the tasks they perform in their professional lives are, usually, more likely to postpone their decision to retire (Kautonen, Hytti, Bögenhold \& Heinonen, 2012; Mein et al., 2000; Oakman \& Wells, 2013). When intrinsic rewards dominate, compared to extrinsic ones, the chances of not considering retirement are higher (Kosloski, Ekerdt \& DeViney, 2001). In the decision to retire, it seems that organizational commitment also matters, which is negatively related to retirement (Adams, Prescher, Beehr \& Lepisto, 2002). At the same time, if employees have a longstanding job with the same organization, and few changes during their working lives, they will be more likely to retire (Davies \& Cartwright, 2011) on average five years before other employees (Oakman \& Wells, 2013). Also, employees with higher pay grades tend to retire more quickly (Mein et al., 2000). Position within an organization may also be associated with the decision to retire. For instance, employees who are in a lower position in an organization have a tendency to withdraw faster from their professional activity (Wahrendorf, Dragano \& Siegrist, 2013). At the same time, 
demands related with professional activities may have an impact on the decision to remain professionally active or to retire.

Stressful activities, characterized by low levels of control of work outcomes and a high effort-reward imbalance, are more likely to facilitate the retirement of older employees (Blekesaune \& Solem, 2005; Wahrendorf et al., 2013). Stress, caused by intense physical demands related to work, can facilitate the decision to retire; people who have intense physical activities are more likely to retire (Jex \& Grosch, 2013). High physical demands can be problematic with advancing age as many physical abilities, necessary to sustain physically intense activities, decline with advancing age (Metter, Conwit, Tobin \& Fozard, 1997; World Health Organization, 1998). Pleasant and gratifying social relationships at work can have also an impact on retirement decisions. Older employees, who are surrounded by co-workers who are friendly, helpful and who do not discriminate on the basis of age retire later, and at the same time think less about retirement (Kosloski et al., 2001).

\section{Retirement adjustment}

The decision to retire leads to a readjustment to new life conditions, new possibilities and new obstacles. Numerous studies have compared well-being or life satisfaction, both before and after older employees have retired. In this way, they try to answer the question of whether retirement increases or decreases well-being and life satisfaction. For example, the study of Latif (2011) found that retirement has a positive impact on the well-being of employees aged 55 and older. Adults who retired voluntarily present a higher level of well-being compared to adults who did not have the option to voluntarily retire and continued in their professional activity (Isaksson \& Johansson, 2000).

However, there is a different trajectory depending on the length of time since retirement took place. At six months, well-being decreased, but after one year of retirement well-being increased (Richardson $\&$ Kilty, 1991). It seems there are many factors that can affects one's adjustment after retirement, not just the length of time since retirement. Level of well-being after retirement, compared with levels of wellbeing during an active professional life may vary, and can depend on the characteristics of employment pre-retirement. Positive, rewarding experiences in pre-retirement employment, together with high status and prestige related to pre-retirement work (Schmidt \& Lee, 2008) leads to retirement being perceived as a loss and a painful moment. However, if the pre-retirement job was a negative experience then retirement is perceived as a reward (Osborne, 2012). At the same time, employees who have worked in the public sector compared to those in the private sector, permanent workers compared to temporary workers, and employees who have worked more than 20 years compared to those that have worked less than 20 years are more adjusted after retirement (Fadila \& Alam, 2016).

Individual factors and not just factors related to the pre-retirement organizational context also contribute to adjustment in retirement. For example, older adults with greater financial comfort are more likely to report fewer adjustment problems after retirement (Fouquereau, Fernandez, Fonseca, Paul \& Uotinen, 2005). Also, health factors and the recent death of a life partner have an impact on well-being after retirement (Beck, 1982).

\section{A special category of retirees}

However, many of the factors related to the decision to retire and to the adjustment to retirement, are factors that have been identified by the literature as being specific to retirment in old age. However, there is a category of retirees that is atypical. This is the case of the members of the military. Professionals in this category retire a few decades earlier than do civilians (Warner, 2008), although many of 
them engage in a second, civilian career (Yair, 2012).

However, this transition from one career to another may generate specific challenges. For instance, there may be a mismatch between the professional training they have received in the military field and the training and skills required as part of the civilian labor force (Wenger, 2017). This is not necessarily the case for the higher ranked armed forces professionals, who often make the transition to civilian management, education, nonprofit organizations and government jobs (Ulrich, 2015). It has also been revealed that such individuals transition in a smooth way to this second career (Baruch \& Quick, 2007).

An important factor in the successful adjustment to retirement on the part of military personnel is the degree of preplanning for retirement and the involvement of family members in this (Fuller \& Redfering, 1976). Planning may be an important factor in adjusting to retirement due to the fact that military employees face specific problems that require strategy and planning. They face the problem of the need to access a new job in civilian life, they face new financial arrangements, a new social position, new life and household patterns, new residential arrangements, more frequent family relations and so on (Bellino, 1969).

Reviewing the literature, it can be observed that very few studies exist that take into account the adjustment of this particular segment of society.

\section{Conclusions}

Retirement is a process that involves many factors before and after making the decision to retire. Knowing the possible dynamics of the retirement process can facilitate the development of intervention plans to optimize its course. All of these are useful in a context where many people will retire due to major increases in longevity (United Nations, 2017).

\section{REFERENCES}

Adams, G., Prescher, J., Beehr, T., \& Lepisto, L. (2002). Applying work-role attachment theory to retirement decision-making. International Journal of Aging Human Development, Vol. 54, Issue 2, 125-137.

Administration on Aging for Community Living. (2015). A Profile of Older Americans: 2015, available at: https://aoa.acl.gov/aging_statistics/profile/2015/docs/2015-Profile.pdf, accessed on 15 September 2019.

Baruch, Y., \& Quick, J. C. (2007). Understanding second careers: Lessons from a study of U.S. navy admirals. Human Resource Management, Vol. 46, Issue 4, 471-491. doi:10.1002/hrm.20178.

Beck, S. H. (1982). Adjustment to and Satisfaction with Retirement. Journal of Gerontology, Vol. 37, Issue 5, 616-624.

Beehr, T. A., \& Bowling, N. A. (2013). Variations on a retirement Theme: Conceptual and operational definitions of retirement. In Wang, M. (Eds.). The Oxford handbook of retirement (pp. 42-55). New York: Oxford University Press.

Bellino, R. (1969). Psychosomatic problems of military retirement. Psychosomatics, Vol. 10, Issue 5, 318-321. doi:10.1016/s0033-3182(69)71721-2.

Blekesaune, M., \& Solem, P. E. (2005). Working conditions and early retirement: A prospective study of retirement behavior. Research on. Aging, Vol. 27, 3-30.

Brunello, G., \& Langella, M. (2012). Bridge jobs in Europe. IZA Discussion Paper, No. 6938.

Bowlby, G. (2007). Defining retirement. Statistics Canada, Catalogue no. 75-001-XIE. 
Costa, D. L. (1998). The evolution of retirement. In Costa, D. L. (Eds) The evolution of retirement: An American economic history, 1880-1990 (pp. 6-31). Chicago: University of Chicago Press.

Crampton, A. (2009). Global aging: emerging challenges. The Pardee Papers, No. 6, 1-39.

Davies, E. M. M., \& Cartwright, S. (2011). Psychological and psychosocial predictors of attitudes to working past normal retirement age. Employee Relations. Vol. 33, Issue 3, 249-268.

Denton, F. T., \& Spencer, B. G. (2009). What is retirement? A review and assessment of alternative concepts and measures. Canadian Journal on Aging, Vol. 28, Issue 1, 63- 76.

Dobriansky, P. J., Suzman, R. M., \& Hodes, R. J. (2007). Why population aging matters-a global perspective. National Institute of Aging, National Institutes of Health, US Departament of Health and Human Services.

Erber, J. T. (2013). Aging \& older adulthood. West Sussex, UK: Wiley Blacwell.

Fadila, D. E. S., \& Alam, R. R. (2016). Factors affecting adjustment to retirement among retirees' elderly persons. Journal of Nursing Education and Practice, Vol. 6, Issue 8, 112-122.

Fouquereau, E., Fernandez, A., Fonseca, A. M., Paul, M. C., \& Uotinen, V. (2005). Perceptions of and satisfaction with retirement: A comparison of six European Union countries. Psychology and Aging, Vol. 20, Issue 3, 524-528.

Fuller, R. L., \& Redfering, D. L. (1976). Effects of preretirement planning on the retirement adjustment of military personnel. Sociology of Work and Occupations, Vol. 3, Issue 4, 479-487. doi:10.1177/009392857634005.

Gruber, J., \& Wise, D. A. (1998). Social security and retirement around the world. Research in Labor Relations Review, Vol. 18, 1-40.

Isaksson, K., \& Johansson, G. (2000). Adaptation to continued work and early retirement following downsizing: Long-term effects and gender differences. Journal of Occupational and Organizational Psychology, Vol. 73, Issue 2, 241-256.

Jex, S. M., \& Grosch, J. (2013). Retirement decision making. In Wang, M. (Eds.). The Oxford handbook of retirement (pp. 42-55). New York: Oxford University Press.

Kautonen, T., Hytti, U., Bögenhold, D., \& Heinonen, J. (2012). Job satisfaction and retirement age intentions in Finland. International Journal of Manpower, Vol. 33, Issue 4, 424-440.

Kosloski, K., Ekerdt, D., \& DeViney, S. (2001). The role of job-related rewards in retirement planning. The Journals of Gerontology: Series B, Vol. 56, Issue 3, 160-169.

Latif, E. (2011). The impact of retirement on psychological well-being in Canada. The Journal of Socio-Economics, Vol. 40, Issue 4, 373-380.

Mein, G., Martikainen, P., Stansfeld, S. A., Brunner, E. J., Fuhrer, R., \& Marmot, M. G. (2000). Predictors of early retirement in British civil servants. Age and Ageing, Vol. 29, Issue 6, 529-536.

Metter, E. J., Conwit, R., Tobin, J., \& Fozard, J. L. (1997). Age-sssociated loss of power and strength in the upper extremities in women and men. Journal of Gerontology: Biological Sciences, Vol. 52A, Issue 5, 267-276.

Oakman, J., \& Wells, Y. (2012). Retirement intentions: what is the role of push factors in predicting retirement intentions?. Ageing and Society, Vol. 33, Issue 6, 988-1008.

Osborne, J. W. (2012). Psychological effects of the transition to retirement. Canadian Journal of Counselling and Psychotherapy, Vol. 46, Issue 1, 45-58.

Richardson, V., \& Kilty, K. M. (1991). Adjustment to retirement: Continuity vs. discontinuity. The International Journal of Aging and Human Development, Vol. 33, Issue 2, 151-169. 
Schmidt, J. A., \& Lee, K. (2008). Voluntary retirement and organizational turnover intentions: The differential associations with work and non-work commitment constructs. Journal of Business Psychology, Vol. 22, 297-309.

Topa, G., Moriano, J., Depolo, M., Alcover, C., \& Morales, J. (2009). Antecedents and consequences of retirement planning and decision-making: a meta-analysis and model. Journal of Vocational Behavior, Vol. 75, 38-55.

Ulrich, M. P. (2015). "Cashing in" stars does the professional ethic apply in retirement?, available at: https://apps.dtic.mil/dtic/tr/fulltext/u2/a624940.pdf, accessed on 10 September 2019.

United Nations, Department of Economic and Social Affairs, Population Division. (2009). World Population Prospects: The 2008 Revision, Highlights (ESA/P/WP.210) New York. US: United Nations publication. The evolving history of retirement within the United States. In M. Wang (Eds.). The Oxford handbook of retirement (pp. 10-21). New York: Oxford University Press.

United Nations. (2017). World Population Prospects: The 2017 Revision, Key Findings and Advance Tables. Working Paper, No. ESA/P/WP/248, available at: https://esa.un.org/ unpd/wpp/Publications/Files/WPP2017 KeyFindings.pdf, accessed on 02 October 2019.

Wahrendorf, M., Dragano, N., \& Siegrist, J. (2012). Social Position, Work Stress, and Retirement Intentions: A Study with Older Employees from 11 European Countries. European Sociological Review, Vol. 29, Issue 4, 792-802.

Warner, J. T. (2008). Thinking about military retirement: An analysis for the 10th QRMC, available at: https://www.cna.org/CNA files/PDF/D0017798.A1.pdf, accessed on 16 September 2019.

Wenger, J. B., Pint, E. M., Piquado, T., Shanley, M. G., Beleche, T. B., Bradley, M. A., Welch, J., Werber, L., Yoon, C., Duckworth, E. J., \& Curtis. N. H. (2017). Soldiers leverage army knowledge, skills, and abilities in civilian jobs. Santa Monica, CA: RAND Corporation.

Wheaton, F., \& Crimmins, E. M. (2013). The demography of aging and retirement. In Wang, M. (Eds.). The Oxford handbook of retirement (pp. 22-41). New York: Oxford University Press.

World Health Organization. (1998). Growing older - staying well. Ageing and physical activityin everyday life, available at: http://apps.who.int/iris/bitstream/10665/65230/ 1/WHO HPR AHE 98.1.pdf, accessed on 10 October 2019.

Yair, G. (2012). The transition of retired military officers to a second career in sport management: The israeli case. Journal of Multidisciplinary Research, Vol. 4, Issue 2, 5-17.

Zickar, M. J. (2013). The evolving history of retirement within the United States. In Wang, M. (Eds.). The Oxford handbook of retirement (pp. 10-21). New York: Oxford University Press. 